\title{
Improving Mathematical Teachers Competency 21th Through Workshop Development Of Mathematical Olympic Problems Based On High Order Thinking Skills In Smp Solok Selatan District
}

\author{
Ali Asmar ${ }^{1}$, Arnellis ${ }^{\# 1}$, Dony Permana ${ }^{1}$, Elita Zusti Jamaan ${ }^{1}$, Nonong Amalita ${ }^{1}$ \\ ${ }^{1}$ Jurusan Matematika Fakultas Matematika dan Ilmu Pengetahuan Alam Universitas Negeri Padang \\ Jln Prof Dr Hamka Air Tawar Padang, West Sumatera, Indonesia \\ \#Correspondence: arnellis math@fmipa.unp.ac.id
}

Diterima 26 Desember 2018, Disetujui 4 Maret 2019, Dipublikasikan 30 November 2019

\begin{abstract}
The aim of study to improve competency junior high school mathematics teachers in Solok Selatan district in compiling Olympiad questions mathematics and solving problems based on high order thinking skills (HOTS). The target audience for community service is mathematics teachers incorporated in the Subject Mathematics Teacher's Consultation (MGMP) Mathematics in Solok Selatan. The method used in the service includes the presentation of material by the team community service then carried out the pre test and post test, the design of the question HOTS, discussion and question and answer sessions at the math Olympiad. Conclusions of this research is: There is a positive increase in teacher competency after being given training in compiling math Olympiad questions that the posttest results are better than the results pretest in the training to improve the competency of mathematics teachers in compiling the questions Mathematical Olympiad based on high order thinking skills of SMPN in Solok Selatan District
\end{abstract}

Keywords: competency, mathematics olympiad, high order thinking skills, $21^{\text {st }}$ century

This is an open access article distributed under the Creative Commons 4.0 Attribution License, which permits unrestricted use, distribution, and reproduction in any medium, provided the original work is properly cited. (C2017 by author and Universitas Negeri Padang.

\section{Introduction}

Teacher competency has been increasing, but it is still far from expectations. should good education, not only good infrastructure, but also the teacher must be of good quality and professional. Educational experts often asserting that teachers are very human resources determine the success of the education program. Whatever has been done for improving the quality of education is not possible without improving quality teacher performance [1]. Therefore in answering the challenges at the age of globalization, improving the quality of teacher performance must absolutely be done continuously in order to improve the quality of education. Given the results that have been achieved by teachers. It can be seen from the increase in teacher competency, especially in the absence of teachers who can represent the junior high school mathematics teacher from Solok Selatan district to national level. This is also supported by the achievement of students who have not once represented a mathematics Olympiad to the national.

Based on the results of observations and interviews with partners, namely some mathematics teachers at Solok Selatan, having difficulties in understanding mathematics Olympiad material where they asked for the training activities to continue, especially 
discussing material mathematics Olympiad, The present condition of 21 st century mathematics teachers is expected to be able to adapt with various learning styles and learning models. The intended teacher collaborator that mathematics teachers are expected to be able to take advantage of 21 st century learning devices as a tool to enrich insight and attract students. Therefore, the teacher must also share ideas and contribute to the development of the device learning mathematics in the 21st century. Paying attention to the needs of mathematical skills 21 st century, a learning device is needed that prepares students so have 4'Cs skills (critical, creative, communication and collaboration) [2].

Teacher competency development can be done through coaching and teacher empowerment. Thus an effort to improve service quality is needed learning. So that the conclusion mathematics partners need to improve special competence in making Olympic learning devices so that the teacher have skills in compiling mathematicsbased Olympiad teaching materials HOTS.

Based on this and considering funding, we will implement it service activities in the form of increasing teacher competency in designing lesson plans and Mathematics Olympiad teaching materials based on high order thinking skills. To facilitate increasing the competence of junior high school teachers in Solok Selatan district, then as one educational institutions that educate educative candidates, Mathematics Department of Mathematics and Natural Sciences UNP needs to participate in helping the problem of teacher limitations in make math questions for the Olympic level, so they can give debriefing to students who excel. One program that is needed is done is training in making teaching materials and mathematics Olympic questions enriching the material for teachers in junior high school, as a form of dedication to community, which is held by lecturers in the Mathematics Department related to the material learned at school.
Furthermore, Solok Selatan District is very potential to be developed in various aspects. In the field education, information is obtained that, there is still much that needs to be addressed related to the quality of education in the villages includes the quality of education math in middle school. This situation needs to get an in-depth study for the community education practitioners to find out the causal factors and find solutions. In addition, activities related to upgrading or training are related refreshment of mathematics Olympiad teaching material is very rarely held. Based on consideration, the location of this service is a center in the region hills, location selection is done to overcome the achievements of students and also teachers towards the mathematics Olympiad, which is the underachievement of students in the Olympics teacher skills in designing Olympic teaching materials based on HOTS are expected the teacher can always explore math Olympiad through an Olympic question bank it has.

Thus, increasing the competence of these teachers is expected to provide implications for students, namely the formation of students in the mathematics Olympiad group so that it is expected to make achievements in various Olympic race events mathematics

HOTS (higher order thinking skills) is a thinking skill that occurs when person takes new information and information that has been stored in his memory, then links that information and submits it to achieve the goals. In Bloom's Taxonomy, skills that involve analysis, synthesis, and evaluation include higher-order thinking skills.[3] The importance of mastering higher order thinking skills in high school founded in some points of the Graduates Competency Standards of Secondary School. The points are teacher can build and apply information or knowledge in a logical, critical, creative, and innovative way; demonstrate the ability to think logically, critically, creatively, and innovatively 
in decision making; as well as demonstrate the ability to analyze and solve complex problems.

\section{Solution}

This community service activity is carried out in forms of material enrichment training and workshops. Enrichment of material provided about math Olympiad. Meanwhile, training / workshops are used for activities preparation of HOTS-based mathematics teaching materials to junior high school teachers in the MGMP Solok Selatan district. Implementation of steps in implementing the solution offered to overcome the problem there are as follows: 1. At first, all participants were given pre tests, with the same quality questions with math Olympiads that have been prepared and prepared by the team community service 2 . Based on the pre test, which material is investigated / analyzed which must be given intensively. 3. On the results of the analysis in step 2, the participants are given enrichment of materials that are considered not yet mastered by the participants. 4 . Furthermore, after the material enrichment is considered sufficient, step by step next is providing training in preparing mathematics teaching materials HOTS. 5. To measure the success of the participants, a post test was given to the teacher junior high school mathematics. 6. To evaluate the implementation of this activity, an evaluation questionnaire is given activities. The design of evaluating the implementation of this service activity is as follows: 1.The initial evaluation is a pre-test that is useful for exploring initial abilities as a basis for determining which materials should be given. 2 . The final evaluation is in the form of a post-test that is useful to see the level of progress after the participants were given enrichment and training in preparing the Olympic questions mathematics. 3. Evaluation of the implementation is carried out by giving a questionnaire, which is will measure the level of success of this activity The indicators of the success of the evaluation activities carried out are: 1.Teacher's knowledge of mathematics Olympiad material increases, with pay attention to the increase in the value of the pre test to the test post 2. More than $75 \%$ of teachers who take part in this activity are able to compile teaching materials
HOTS based mathematics. 3. The level of satisfaction of participants from the results of filling in the activity questionnaire exceeded 3 in scale 4.

\section{Result And Discussion}

This community service activity is aimed at junior high school teachers in Solok Selatan regency. From this community service activity it is known that mathematics teachers are joined in the MGMP mathematics teacher in Solok Selatan district very enthusiastic and felt that this activity is really needed and provides great benefits for they. From the implementation of this activity the teacher is able to make and design questions then resolve the case or questions in the form of nonroutine questions which require reasoning and high-level thinking. During this time the motivation of the teacher to discuss and solving problems with an Olympic level is not so good. This is because in delivering the material in the question class given is not as high and as difficult as the questions at Olympic. In addition there are still teachers who are pessimistic in fostering their students because of reasons for many rivals and impossible to win. This community service activity begins with preparation activities, namely design the material and questions that will be tested to the teacher and discussed together. Then proceed with the design of activities in making and solving questions Olympic. Arrange questions about the pre test and test post. In addition, a questionnaire was also formulated entries that must be filled in by each teacher participating in the activity.

\section{Activities at the first and second meetings:}

21st Century Mathematics MGMP Teacher Competency Enhancement Workshop Mathematics Olympic Training Based on High Order Thinking Skills in Solok Selatan. This activity begins with the management of a research permit from the community service agency. In the 
Community and determination of the training participants' schedule with the head of the district MGMP SMP Solok Selatan This activity consists of several forms of activities, namely: socialization, workshop / training. Socialization activities are held on Saturday and Sunday September 22 and 23, 2018, in this activity general information about the Olympics was given junior high school mathematics, teachers pay attention to the mathematics Olympiad material and practice making questions designing Olympic questions based HOTS. For more details about each of these activities will be explained in the following sections: 1. Dissemination of mathematics Olympiad material This socialization activity consists of two forms: a. Opening and remarks by the secretary of the education office district of Solok Selatan. This activity begins with a speech and an official opening ceremony by the office secretary education in Solok Selatan Regency and continued remarks from the chairman of the MGMP SMP Solok Selatan b. Introduction of mathematics Olympiad and the importance of mathematics Olympiad and designing HOTS itembased Olympic questions in improving the quality of learning and improve teacher professionalism. After that, continue with pre test The second session was held after a break, mid day prayer and lunch, with activities: a. Explanation of material for algebra, number theory and sample Olympic problems b. Discussion and question and answer, in this section the participants were given the opportunity to ask everything related to the material of number theory. The activity on the first day received great attention from the participants, at first the participants looked somewhat apathetic, because the teacher's mindset suspected junior high school Olympics material was difficult, even thought high school material was not the teacher as the builder. But after the teacher was invited paying attention to what the teacher has taught at school can be developed and modified from routine questions to non-routine questions, the teacher was enthusiastic and enthusiastic about asking. In this session The teacher designed the Olympic questions in groups under the guidance other team members. After the problem is made and taken, then the question the questions that have been made are exchanged for other groups to be able to solve them. In the following figure, activity of training in MGMP SMP Solok Selatan

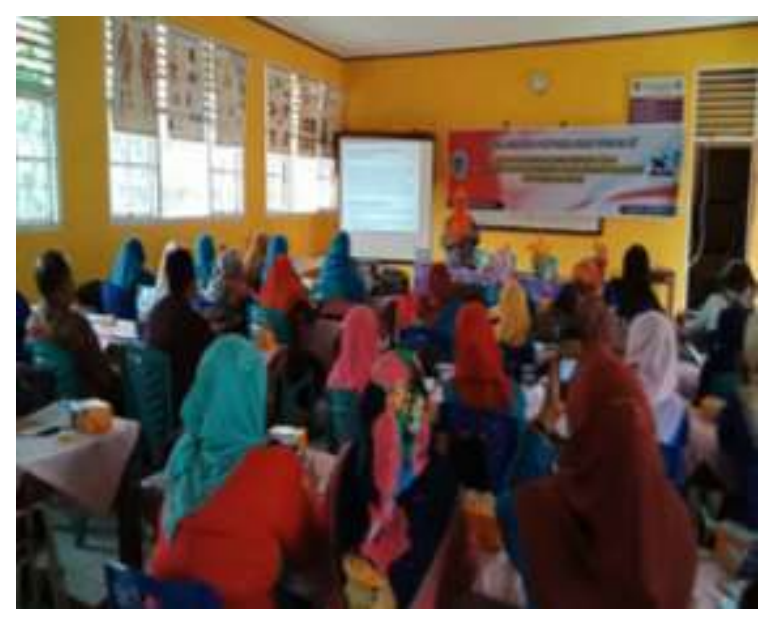

Picture 1. Presentatin of Number Theory by Dra. Arnellis,M.Si

\section{Activities at the third and fourth meetings:}

The second activity or presentation is about HOTS material in 21st century mathematics teachers This activity is held on Saturday and Sunday on the 6th and 7th October, 2018. This activity is carried out by providing teachers with reminders HOTS learning material that will be taught in class IX is continued with explanation about design about HOTS. After that followed by discussion and question and answer, on this section the participants were given the opportunity to ask everything related with HOTS material. During the afternoon session the teacher designed an Olympic question group under team members. After the problem finished and taken, then the questions that have been made are exchanged for other groups to be able to finish it. The activity on Sunday was completed and material was obtained HOTS reinforcement material, question design 
and discussion. The activity can be seen the following figure

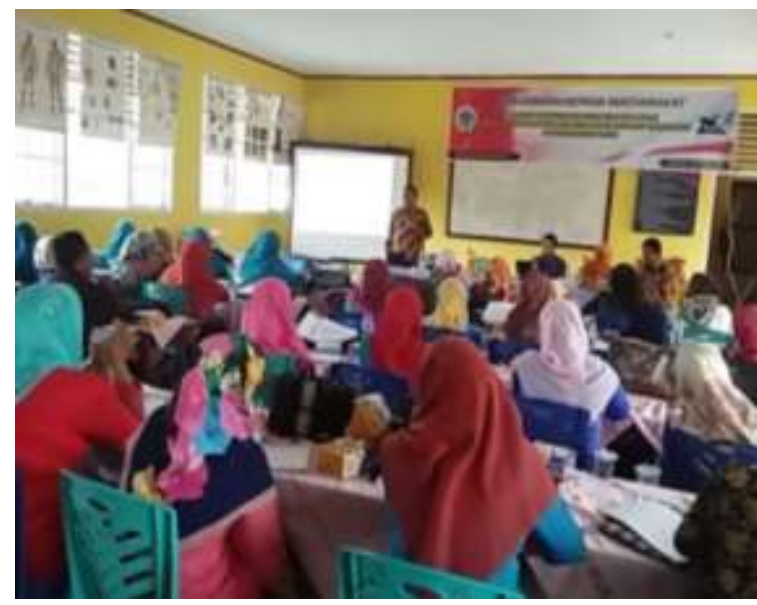

Picture 2. Presentatin of Number Theory by Dr. Ali Asmar,M.Pd

\section{Activities at the fifth and sixth meetings:}

In the third activity presented with material Geometry and Combinatorial. This activity is held on Sunday the 20th and 21st October 2018. This activity is not much different from the previous meeting and also generated material reinforcement of geometry and combinatorial, Olympic-based design questions based on HOTS and discussion. The results have been achieved through efforts to improve the competence of junior high school mathematics teachers Solok Selatan regency from the form of enrichment and training can complete the process good quality learning is expected to be a Mathematics teacher for Solok Selatan district can build student Olympics competitions. Enrichment models and competency improvement training the teacher in making math Olympiad questions becomes a better value, and can more widely replicated to other mathematics teachers in Solok Selatan district, to form an optimization of teacher activities in the Mathematics MGMP SMP. The results have been achieved through efforts to improve the competence of junior high school mathematics teachers Pesisir Selatan Regency from the form of enrichment and training can complete the process good quality learning is expected to be a Mathematics teacher for Solok Selatan district can build student Olympics competitions. Enrichment models and competency improvement training the teacher in making math Olympiad questions becomes a better value, and can more widely replicated to other mathematics teachers in Solok Selatan district to form an optimization of teacher activities in the Mathematics MGMP as in the following figure

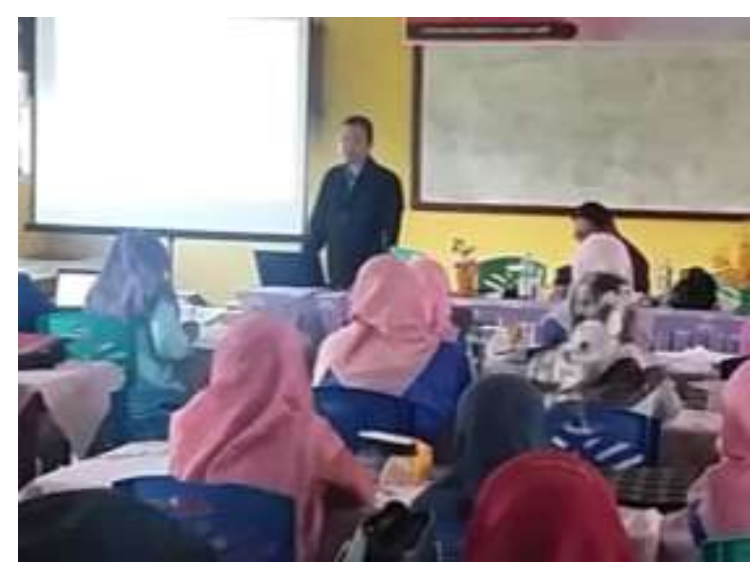

Picture 3. Presentatin of Number Theory by Dr. Dony Permana,M.Si

Based on the evaluation activities carried out, the indicators of the success of this activity is: Teacher's knowledge of HOTS-based mathematics Olympiad material increases, taking into account the increase in the pre-test scores to the test post This is shown in the following table

Table 1. Results of Data Analysis Pretest and Posttest.

\begin{tabular}{cccccc}
\hline Test & Max & Min & Mean & Varians & $\begin{array}{c}\text { Deviation } \\
\text { Standard }\end{array}$ \\
\hline $\begin{array}{c}\text { Pre } \\
\text { test }\end{array}$ & 62.5 & 17.5 & 41,52 & 167.96 & 12.96 \\
\hline $\begin{array}{c}\text { Post } \\
\text { test }\end{array}$ & 90 & 12.5 & 54.85 & 170.04 & 13.04 \\
\hline
\end{tabular}

\section{Conclusion}

There is a positive increase in teacher competency after being given training in compiling math Olympiad questions based on high order thinking skills in junior high school teachers in Solok Selatan Regency. This is indicated by the value of the posttest result is higher than the value 
of the pre test. So it can be concluded that the post test results are better than the results pretest in the training to improve the competency of mathematics teachers in compiling the questions Mathematical Olympiad based on high order thinking skills of SMPN in Solok Selatan District. 1. Obtained material enrichment for teachers on mathematics material and Mathematics Olympiad in the form of Mathematics Olympiad teaching books. 2. Obtained non-routine math questions to the teacher, namely through introduction of mathematics Olympiad questions based on high order deep thinking skills HOTS-based math Olympiad questions bank forms

\section{Suggestions And Recommendations}

The service activities that have been carried out should be followed up by the department education in Solok Selatan district so that what has been obtained during the training can developed and disseminated to other math teachers and especially to students who will take part in the Olympic race

\section{Acknowledgment}

We thank to mathematics teachers of SMP Solok Selatan and State University of Padang had been supported by facilities in this training activities.

\section{References}

[1] Rofiah, Emi., Aminah, NS and Ekawati, EY 2013. "Preparation of Test Instruments High Level Physics Thinking Ability in Middle School Students "Education Journal

[2] NEA, 2011, Preparing $21^{\text {st }}$ Century Students for a Global Society: An Educator's Guide to the "Four Cs", Washington: NEA

[3] Karthwohl. 2002. A revision of Bloom's Taxonomy: An Overview. Taylor and Fracis. Theory into Practice Vol. 41, No. 4 pp 212218Anderson, LW and Krathwohl, DR., 2001. A Taxonomy for Learning, Teaching, and Assessing. New York: Addison Wesley Longman Inc. 